UNIVERSITY OF WAIKATO

Hamilton New Zealand

\title{
The Relationship of Patenting Applications and Expenditure with Output and Real GDP in Nineteenth Century Colonial New Zealand
}

Matthew Gibbons and Les Oxley

\section{Department of Economics}

Working Paper in Economics 17/05

March 2017

\section{Corresponding Author}

Matthew Gibbons

Economics Department Waikato Management School

University of Waikato

Private Bag 3105

Hamilton

NEW ZEALAND, 3216

Email:mgibbons@students.waikato.ac.nz
Les Oxley

Economics Department

Waikato Management School

University of Waikato

Private Bag 3105

Hamilton

NEW ZEALAND, 3216

Phone: +64 (0)7 8384076

Email: les.oxley@waikato.ac.nz 


\begin{abstract}
The relationship between patenting and both output series and real GDP was examined using nineteenth century New Zealand patent applications, and applications weighted by fees and required advertising expenditure. For individual output series and real GDP there were considerably more cointegrating relationships with Granger causality for expenditure than for application counts, suggesting the expenditure data provides a better measure of the value of patents. Output series and real GDP usually led patenting, particularly using patent expenditure data, which indicates patentees were concentrating on economic needs. In some of the results, however, output series and real GDP followed patenting.
\end{abstract}

\title{
Keywords
}

New Zealand patents

Granger causality

patent expenditure

GDP

\section{JEL Classifications}

$\mathrm{O} 31 ; \mathrm{N} 17 ; \mathrm{N} 37 ; \mathrm{N} 87$

\section{Acknowledgements}

We would like to thank the University of Waikato Postgraduate Committee for support provided to the first author. 


\section{Introduction}

This article examines the relationship in New Zealand between patenting, which is measured both using application counts and expenditure on patenting, and economic output series and real GDP. As well as quantifying the total level of patenting, the effect of patenting by people living in New Zealand and overseas and patenting in different economic areas is studied. Because expenditure on each patent was calculated, this article is the first to analyze the relationship between expenditure on patents and economic output series and real GDP.

Reductions in New Zealand patent fees during the 1880s resulted in a sharp increase in patent applications, but most of these additional patent applications were not proceeded with (Gibbons and Oxley 2016). Expenditure on the amount paid to seal and renew patents, therefore, may provide a more accurate representation of the value of patents than just counting patent applications, and may also be more strongly related to economic output and real GDP variables. Reductions in initial patent fees and increases in the proportion of lapsed applications also occurred in Britain, and in other British self-governing Australasian colonies, such as Victoria, during the 1880s (Magee 2000, MacLeod, Tann et al. 2003, pp.555-558). The results presented here for New Zealand, therefore, provide insights into how the to analyze the relationship between patenting and output and real GDP in other patent systems.

Because new unit record data weighted by expenditure was developed, the time period covered is shorter than for studies that have used published summary data on patent applications (Cotter 2006, Greasley and Oxley 2010, Williams and Oxley 2016). This limits the number and type of variables that can be included. Nevertheless, the results reveal whether patenting led or followed output and real GDP, and how this varied for different output areas.

Section two of this article describes the theoretical background. In Section 3, the patents dataset is discussed, while section four outlines key theoretical and methodological time series econometrics concepts used in this article. Section five tests the relationship between output and real GDP and both patent applications and expenditure relating to these topics.

\section{Theoretical Background}

Patents are often justified on the basis that they stimulate economic growth by ensuring that, in exchange for a temporary monopoly, knowledge and inventions are written down and on expiry of the patent become available to others (Dutton 1984, pp.17-22, Auger 1992). Economic historians have therefore researched whether patents play a key role in economic development. However, they have often found that applications lag behind economic development. For instance, in a pioneering study Schmookler (1966, pp.98, 106-107, 138, 
147) found that inventions relating to railways often seemed to follow investment and stock prices, with cause effectively preceding hypothesized effect. Supporting evidence came from other industries and from cross-sectional data which showed increases in patent applications tended to follow increases in investment in physical capital. Schmookler and other researchers found that inventors have responded entrepreneurially to economic problems and opportunities. As a result, inventions are creative responses to economic needs, motivated by potential economic returns (Schmookler 1966, pp.106-107, 111, 119, 136, Khan and Sokoloff 1993, p.289, Hanlon 2015).

Indeed, economic development in Britain during the industrial revolution led patenting (Greasley and Oxley 2007, p.345), with profit providing the main stimulus to invention (Dutton 1984, p.142). Similarly, in colonial Victoria Magee (2000, p.111) found that usually the direction of causality ran from technological and economic need to scientific knowledge, rather than the reverse.

There is also a growing literature on the relationship between patenting and economic growth in New Zealand, although there are still substantial gaps in that literature. Cotter examined whether there was a relationship between total patents and macro-economic variables between 1870 and 1938. Real Gross Domestic Product, exports per capita, real wages, and the money supply had correlations of 0.75 to 0.95 with patents, but real government expenditure (for which she used the Consolidated Account component) was poorly correlated with patenting (Cotter 2006, p.18). The number of patents in force Granger caused real GDP per capita (Cotter 2006, p.22).

Greasley and Oxley have examined the relationship between patenting and economic output in New Zealand in more depth, using data on patent applications in different sectors of the economy. They found patenting in New Zealand typically led output between 1861 and 1939, with this occurring for five out of eight industry groups and for overall commodity output. However, for the key meat sector production led patenting, suggesting that pioneering industries were less likely to be led by patenting (Greasley and Oxley 2010, pp.444, 452, 454).

In addition, Williams and Oxley found an increase in the geographic concentration of flax patents was associated with increased output by New Zealand's agricultural sector. Total patent density in agriculture also boosted sector output consistent with agglomeration effects. Furthermore, the geographic concentration of dairying patents boosted sector output. The results suggested that agglomeration of innovation was only important for output in the dairy and flax industries (Williams and Oxley 2016, pp.164, 169). 


\section{The Patents Dataset}

A new unit record dataset of over 12,000 patent applications made in New Zealand between 1860 and 1899 was developed for this paper. Patents were coded by industry of intended use (Magee 2000).

New Zealand took pride in its high rate of patent capita patent applications, which by the late 1880s was higher than in the United States, Britain, and Victoria and New South Wales (Greenshields 1887, p.4, Evening Star 1889, p.1). In addition, New Zealand patent applications in London exceeded those from any other British colony and possession except Victoria, Canada, and India, and most foreign states (Registrar Patents Office, 1890, p.3). By 1900 New Zealand also had one of the highest living standards in the world, making testing the relationship between patenting and output of interest (Greasley and Oxley 2010, p.450). Nevertheless, counts of patent applications have limitations for understanding investment in patents (Schankerman and Pakes 1986, Griliches 1998, Nuvolari and Tartari 2011). One reason for this is that the number of patent applications in New Zealand, particularly by New Zealanders, sharply increased after initial application costs were reduced during the early 1880 s and compulsory advertising requirements for applications ceased (Gibbons and Oxley 2016). However, a higher proportion of applications lapsed or were not renewed. There was also an increase in lapsed patent applications in Britain during the 1880s after application fees were reduced (Boehm 1967, pp.33-34), while the changes in fees in New Zealand in the 1880 s were also similar to those in the self-governing British colony of Victoria (Magee 2000).

Economists are increasingly weighting patent applications by expenditure on renewal fees, citations, and other variables (Sullivan 1994, Streb, Baten et al. 2006, p.354, Nuvolari and Tartari 2011, pp.98, 105). In addition to simple counts of applications, New Zealand patent applications were therefore weighted by the amount spent on application, sealing and renewal fees for each patent in the year that expenditure occurred. Required expenditure on advertising applications, which between 1871 and 1881 was greater than the cost of applying for and sealing a patent, and parchment costs were also calculated and included (Gibbons and Oxley 2016). Costs for drawings and patent agent fees have not been included due to inadequate information. The method used does not allow for expenditure to have an effect in multiple years, by contributing to the stock of knowledge (Sullivan 1994), but does facilitate direct comparisons with a previous New Zealand study that used patent application counts (Greasley and Oxley 2010).

However, changes in initial application fees had considerably less effect on overseas patent applications, which constituted about 38 percent of total New Zealand applications, than patent applications by New Zealanders. The applications and expenditure data may therefore produce similar results. Unfortunately, patent citations are not available. However, 
the number of full term 14-year patents has been included in section five to provide an alternative quality measurement. Furthermore, total New Zealand and overseas patent applications and expenditure have been included in section five to test whether they have different relationships with output and real GDP series. For instance, New Zealand inventors may have been more aware of New Zealand's technological needs than overseas inventors, or alternatively overseas technological advances may have had a greater economic impact.

\section{Time Series Methodological Issues}

In time-series econometrics the order of integration, which is the number of times a variable needs differencing to ensure stationarity, is important. The order of integration of all the variables in an equation must be the same to ensure a balanced statistical relationship (Greasley and Oxley 2010, p.974). Most economic time-series are non-stationary processes that have no tendency to return to a deterministic trend. They are therefore difference stationary and (typically ${ }^{1}$ ) integrated of order one, which is often written as I(1), since they must be differenced once to become stationary. Nelson and Plosser (1982, p.139) discovered that relatively few United States economic variables show a trend stationary process, which involves stationary fluctuations around a deterministic trend. However, other economists, such as Pierre Perron, have argued that allowing for occasional structural changes, such as the Great Depression, undermines these findings (Perron 1989, p.1382, Hansen 2001, p.125).

When a linear combination of two (or more) I(1) series is $\mathrm{I}(0)$ cointegration exists, and their linear combination constitutes a cointegrating relationship. However, not all integrated variables are cointegrated (Greasley and Oxley 2010, pp. 981-982). A number of alternative methods exist to test for cointegration; however, this work uses the Johansen method where both the trace and maximum eigenvalue tests for cointegration are considered. Granger causality tests establish causality between variables. When two variables are both I(1) and cointegrated a causal relationship exists in at least one direction (Engle and Granger 1987, p.275).

Causality therefore involves determining the order of integration of the variables, and then for I(1) data investigating (in our case) bivariate cointegration. When cointegration exists, there must be one or two way Granger causality, although this may not be detectable in small samples. Granger causality is based upon testing whether one time series is useful for forecasting another time series. If the data are I(1) and cointegrated an error correction model can be constructed in differences (Greasley and Oxley 2010, pp.987-988). This will now be outlined using equations.

\footnotetext{
${ }^{1}$ Non-stationary series can be integrated of order $>1$ which would require that the data be differenced more than once to obtain stationarity. Orders of integration $>1$, however, are unusual in economic applications.
} 
Granger causality tests can use I(1) data if the data is cointegrated. Following Greasley and Oxley's notation (2010, pp. 987-988), for variables X and Y:

$$
\begin{gathered}
X=\propto+\sum_{i=1}^{m} \beta_{i} X_{t-i}+\sum_{j=1}^{n} \gamma j Y_{t-j}+u_{t} \\
Y=a+\sum_{i=1}^{q} b_{i} Y_{t-i} \sum_{j=1}^{r} c j X_{t-j}+v_{t}
\end{gathered}
$$

Here $u_{t}$ and $v_{t}$ are zero mean and serially uncorrelated random disturbances and the lags $\mathrm{m}$, $\mathrm{n}, \mathrm{q}$ and $\mathrm{r}$ are decided using information criteria. This equation is also used for data that is already I(0) (Engle and Granger 1987, p254).

Secondly, for cointegrated variables $\mathrm{I}(0)$ data in differences can incorporate an error correction mechanism (ECM).

$$
\begin{gathered}
\Delta X=\propto+\sum_{i=1}^{m} \beta_{i} \Delta X_{t-i}+\sum_{j=1}^{n} \gamma j \Delta Y_{t-j}+\delta E C M_{t-1}+u_{t} \\
\Delta Y=a+\sum_{i=1}^{q} b_{i} \Delta Y_{t-i} \sum_{j=1}^{r} c j \Delta X_{t-j}+d E C M_{t-1}+v_{t}
\end{gathered}
$$

Thirdly, when data are I(1) but not cointegrated, differencing produces stationarity. The equations used are then the same as three and four, but without the error correction term.

$$
\begin{gathered}
\Delta X=\propto+\sum_{i=1}^{m} \beta_{i} \Delta X_{t-i}+\sum_{j=1}^{n} \gamma j \Delta Y_{t-j}+u_{t} \\
\Delta Y=a+\sum_{i=1}^{q} b_{i} \Delta Y_{t-i} \sum_{j=1}^{r} c j \Delta X_{t-j}+v_{t}
\end{gathered}
$$

For equations 1 and 2, Y Granger causes (GC) X if $H_{0}: \gamma_{1}=\gamma_{2}=\gamma_{3}=\cdots=\gamma_{n}=0$ is rejected against the hypothesis $H_{1}:=$ at least one $\gamma_{j} \neq 0, \mathrm{j}=1, \ldots$, n. Furthermore, X GC Y if $H_{0}: c_{1}=c_{2}=c_{3}=\cdots=c_{r}=0$ is rejected against the hypothesis $H_{1}:$ at least one $c_{j} \neq$ $0, \mathrm{j}=1, \ldots, \mathrm{r}$.

For equations 3 and 4, $\Delta Y$ GC $\Delta X$ if $H_{0}: \gamma_{1}=\gamma_{2}=\gamma_{3}=\cdots=\gamma_{n}=0$ is rejected against the hypothesis $H_{1}:=$ at least one $\gamma_{j} \neq 0, \mathrm{j}=1, \ldots, \mathrm{n}$ or $\delta \neq 0$. Furthermore, $\Delta X$ GC $\Delta Y$ if $H_{0}$ : $c_{1}=c_{2}=c_{3}=\cdots=c_{r}=0$ is rejected against the hypothesis $H_{1}:=$ at least one $c_{j} \neq$ $0, \mathrm{j}=1, \ldots, \mathrm{r}$ or $d \neq 0$. 
For equations 5 and 6 , which involve non-cointegrated data, $\Delta Y$ GC $\Delta X$ if $H_{0}: \gamma_{1}=\gamma_{2}=$ $\gamma_{3}=\cdots=\gamma_{n}=0$ is rejected against the hypothesis $H_{1}:=$ at least one $\gamma_{j} \neq 0, \mathrm{j}=1, \ldots$, n. In addition, $\Delta X$ GC $\Delta Y$ if $H_{0}: c_{1}=c_{2}=c_{3}=\cdots=c_{r}=0$ is rejected against the hypothesis $H_{1}:=$ at least one $c_{j} \neq 0, \mathrm{j}=1, \ldots, \mathrm{r}$.

\section{Explaining Output and Real GDP in Different Parts of the Economy}

This section considers relationships between patent application counts and expenditure on patents with output and real GDP, both in aggregate and in specific areas. ${ }^{2}$ Since total patent applications and total patent expenditure both summarize a diverse range of topics, it is important to look at the relationship between patenting and output in particular economic areas. Indeed, Greasley and Oxley's (2010) output statistics since 1860 show mining and manufacturing followed considerably different trends to the other output areas. ${ }^{3}$

Greasley and Oxley's summary output statistics are used, as are Rankin's (1992) GDP statistics as a traditional measure of total output. The patent application categories are similar to those used by Greasley and Oxley. As a result, pastoralism here includes patents related to dairying and refrigeration (Greasley and Oxley 2010, p.451). Table 1 provides results of unit root tests on these series, which show that most series appear to be I(1). However, some output series such as clothing, engineering, and manufacturing were not I(1) over the period covered, and are therefore excluded from further analysis. In addition, since there were relatively few patents about printing before 1899, print and publishing patents were excluded.

Total New Zealand and foreign patents were included to test whether there were differences in the economic effectiveness of patents from different countries. This follows Cotter (2006, p. 20) who found a causal relationship between real GDP and New Zealand patent applications that did not exist for foreign patent applications, suggesting that only New Zealand patenting caused GDP to grow between 1871 and 1938. Furthermore, 14-year patent applications and expenditure were also included to see if the most costly patents, which could be expected to be of higher quality (Streb, Baten et al. 2006, pp.349-355), had a stronger economic effect than all patents.

\footnotetext{
${ }^{2}$ Results for the relationships between total patent applications and expenditure with total output and GDP after adding further variables were disappointing. Although Magee found that native-born engineers were an important variable explaining patent applications in Victoria (Magee, 2006), statistics were only available for New Zealand censuses from 1886. Levels of urbanisation in New Zealand showed relatively little change, while high quality data on government expenditure is lacking.

${ }^{3}$ Additional results for the mining sector, which shows a different pattern of output to the rest of the economy, are also considered.
} 
Table 1: Unit Root Test Results using Modified Hannan-Quinn Criterion

\begin{tabular}{|c|c|c|c|c|c|c|c|c|c|c|c|c|c|c|c|}
\hline \multirow[b]{2}{*}{ Variable (in logs) } & \multicolumn{5}{|c|}{ Ln Applications } & \multicolumn{5}{|c|}{ Ln Expenditure } & \multicolumn{5}{|c|}{ Ln Output or Real GDP } \\
\hline & $\mathrm{I}$ & Lags & Equation & $\mathrm{ADF}$ & P-value & I & Lags & Equation & $\mathrm{ADF}$ & P-value & $\mathrm{I}$ & Lags & Equation & $\mathrm{ADF}$ & P-value \\
\hline Total patents \& Rankin GDP & 1 & 9 & I & -3.41 & 0.02 & 1 & 9 & I & -10.1 & 0 & 1 & 9 & I & -3.20 & 0.03 \\
\hline Output & & & & & & & & & & & 0 & 9 & $\mathrm{I}, \mathrm{T}$ & -3.58 & 0.04 \\
\hline New Zealand patents & 1 & 9 & I & -3.51 & 0.01 & 1 & 9 & I & -9.37 & 0 & & & & & \\
\hline Foreign patents & 1 & 9 & I & -3.15 & 0.03 & 1 & 9 & I & -3.55 & 0.01 & & & & & \\
\hline Fourteen year term patents & 1 & 9 & I & -9.61 & 0.02 & 1 & 9 & I & -9.47 & 0 & & & & & \\
\hline Agriculture & 1 & 8 & I & -7.27 & 0 & 1 & 8 & I & -10.48 & 0 & 1 & 9 & I & -8.13 & 0 \\
\hline Pastoralism & 1 & 8 & $\mathrm{I}, \mathrm{T}$ & -11.20 & 0 & 1 & 8 & $\mathrm{I}, \mathrm{T}$ & -11.92 & 0 & 1 & 9 & I & -3.57 & 0.01 \\
\hline Clothing & 1 & 9 & I & -8.52 & 0 & 1 & 9 & I & -7.43 & 0 & 0 & 6 & $\mathrm{I}, \mathrm{T}$ & -5.16 & 0.00 \\
\hline Transport, comms, power & 1 & 8 & $\mathrm{I}, \mathrm{T}$ & -11.89 & 0 & 1 & 7 & I & -8.37 & 0 & & & & & \\
\hline Manufacturing & & & & & & & & & & & 2 & 6 & I & -3.00 & 0.05 \\
\hline Mining & 1 & 8 & I & -2.90 & 0.06 & 1 & 8 & I & -8.45 & 0 & 1 & 9 & $\mathrm{I}, \mathrm{T}$ & -7.50 & 0 \\
\hline Engineering & & & & & & & & & & & 2 & 6 & I & -4.87 & 0 \\
\hline
\end{tabular}

Note

I=intercept, T=trend.

Sources: A new unit record New Zealand patent dataset; Greasley and Oxley (2010) for output statistics; Rankin (1992) for GDP. 
Figure 1: Log of Patent Applications

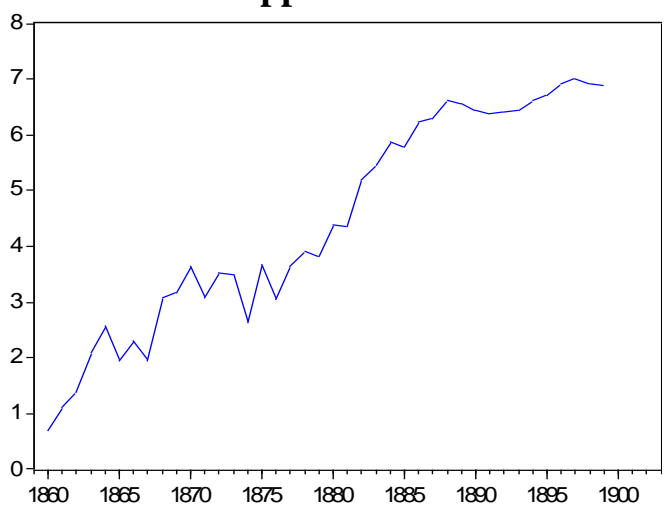

Figure 3: Log of Total Patent Applications by People Living in New Zealand

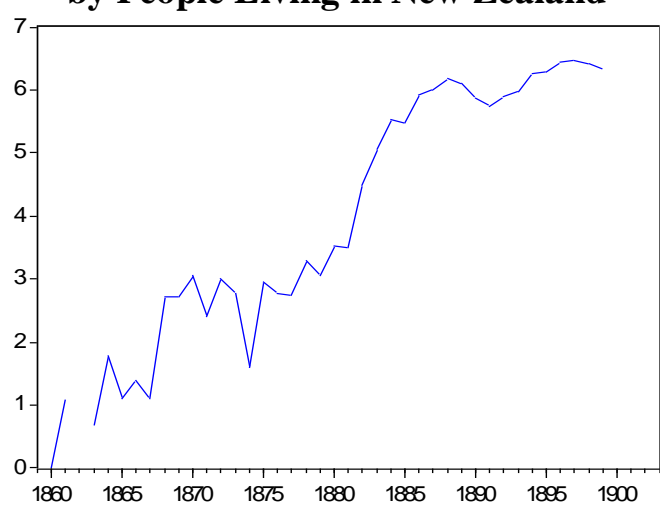

Figure 5: Log of Foreign Patent Applications

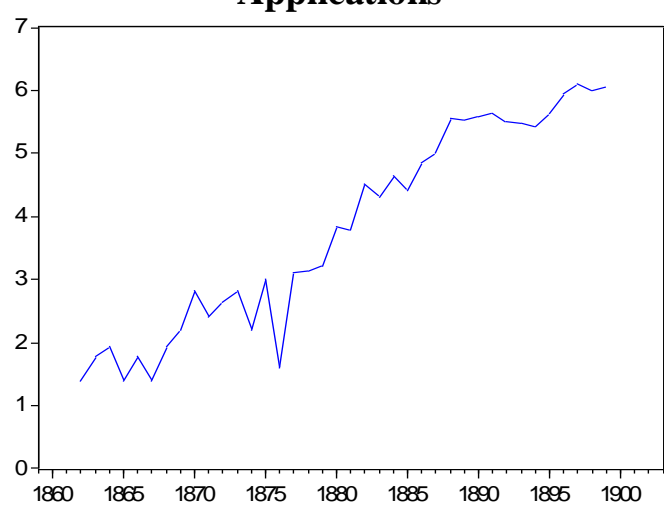

Figure 2: Log of Total Expenditure on Patents

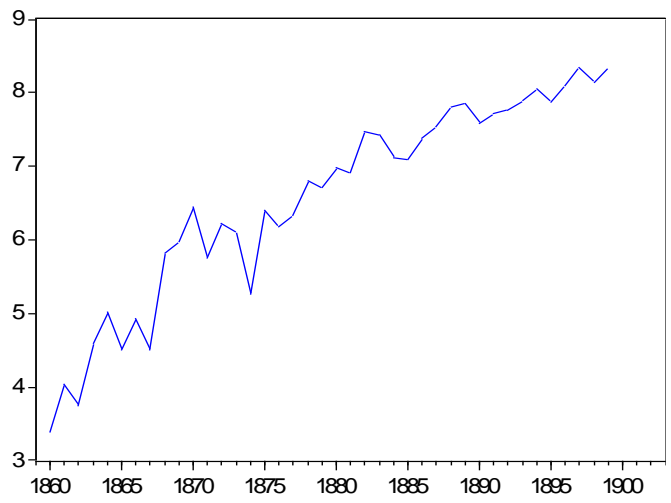

Figure 4: Log of Patent Expenditure by People Living in New Zealand

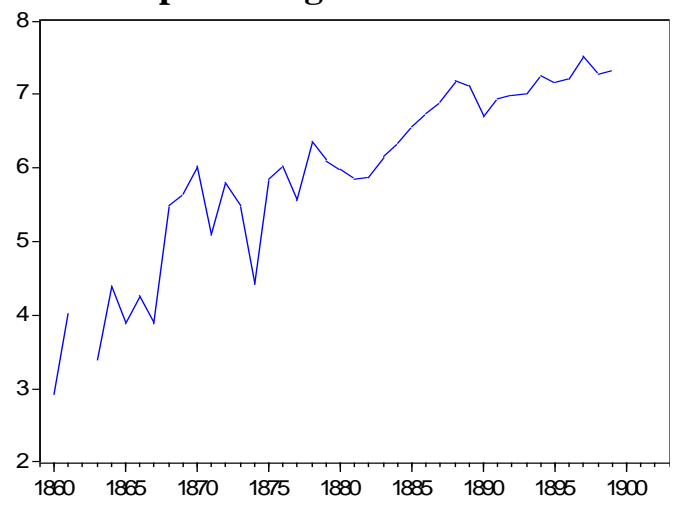

Figure 6: Log of Foreign Patent Expenditure

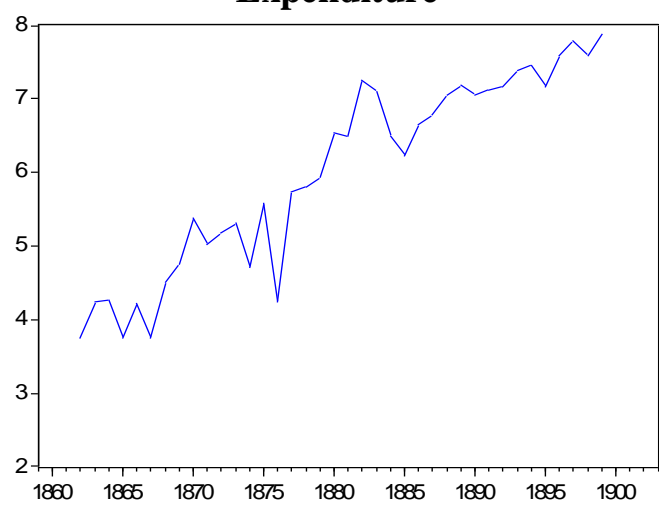


Figure 7: Log of 14-Year Patent Applications

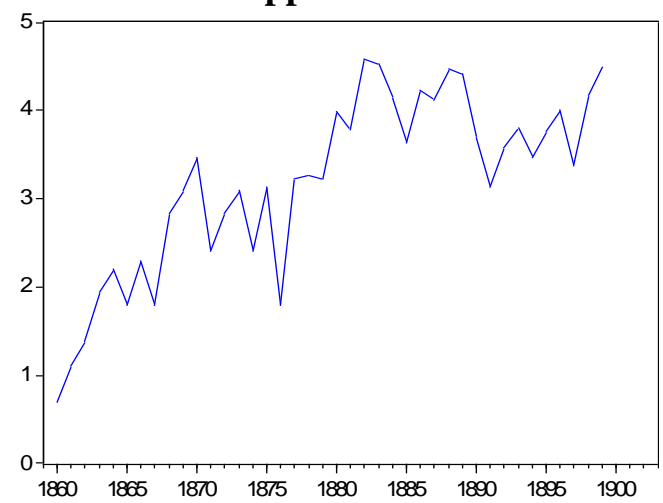

Figure 9: $\log$ of Real GDP

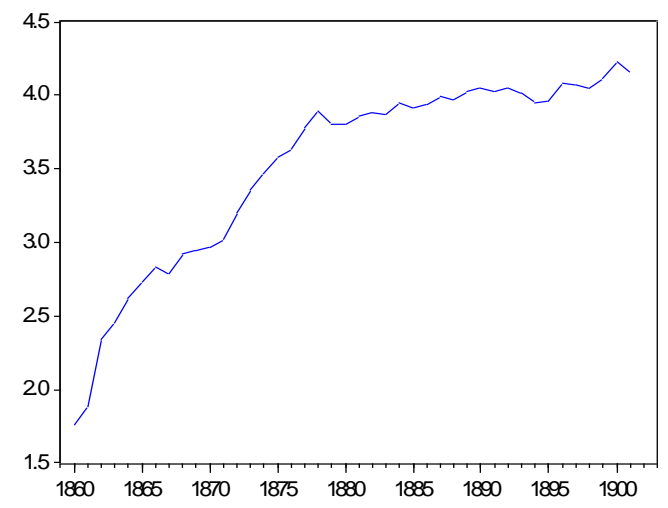

Figure 11: Log of Agricultural Patent Applications

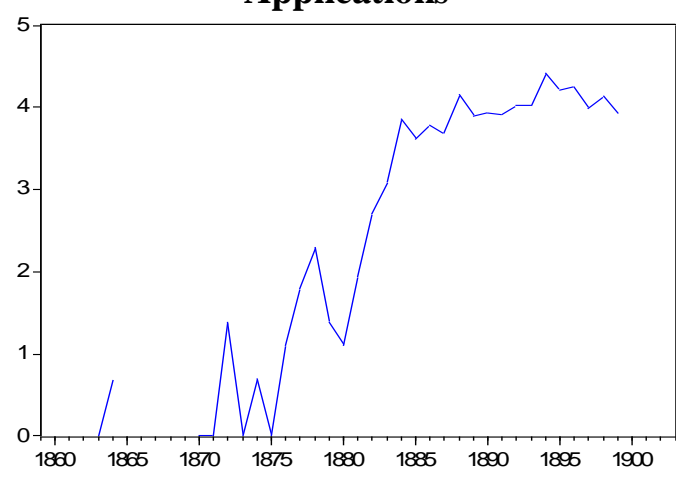

Figure 8: Log of 14-Year Patent Expenditure

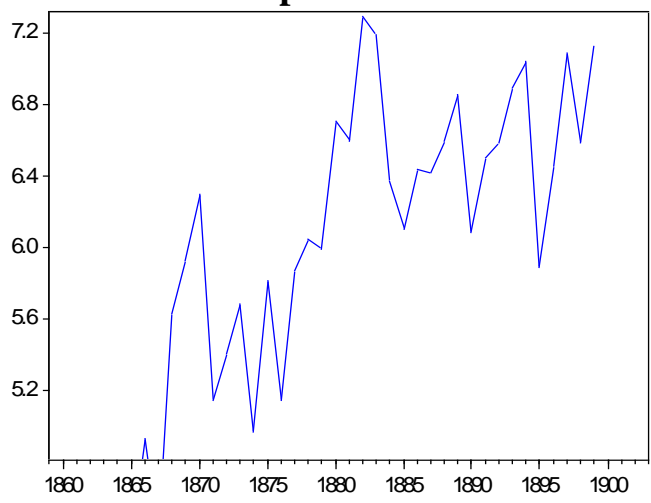

Figure 10: Log of Total Commodity Output

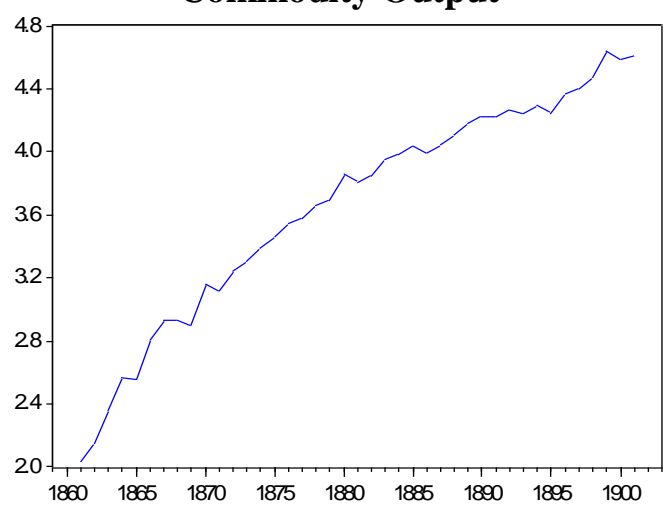

Figure 12: Log of Agricultural Patent Expenditure

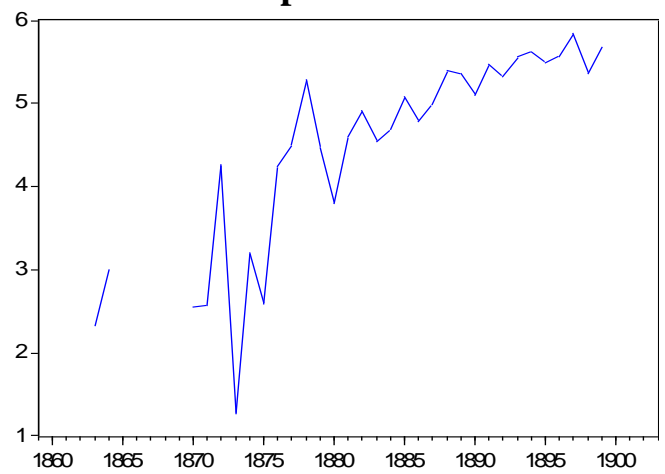


Figure 13: Log of

Agricultural Output

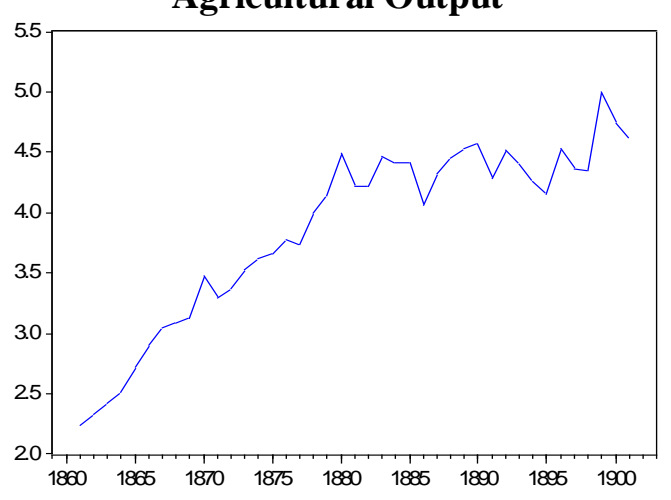

Figure 15: Log of Pastoral Patent Expenditure

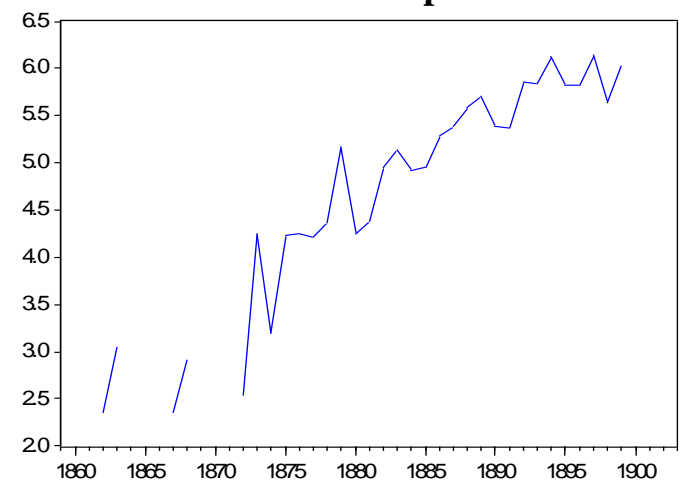

Figure 17: Log of Clothing and Textiles Patent Applications

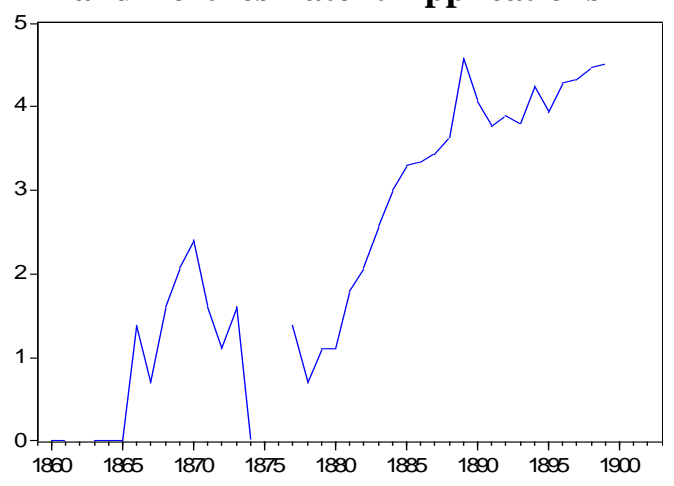

Figure 14: $\log$ of Pastoral Patent Applications

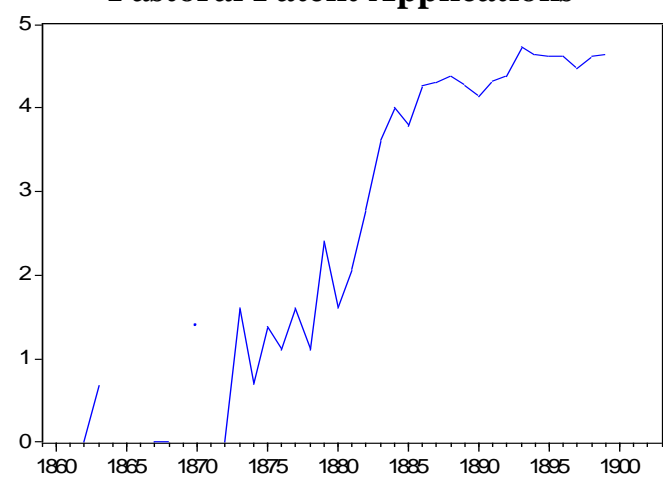

Figure 16: Log of

Pastoral Output

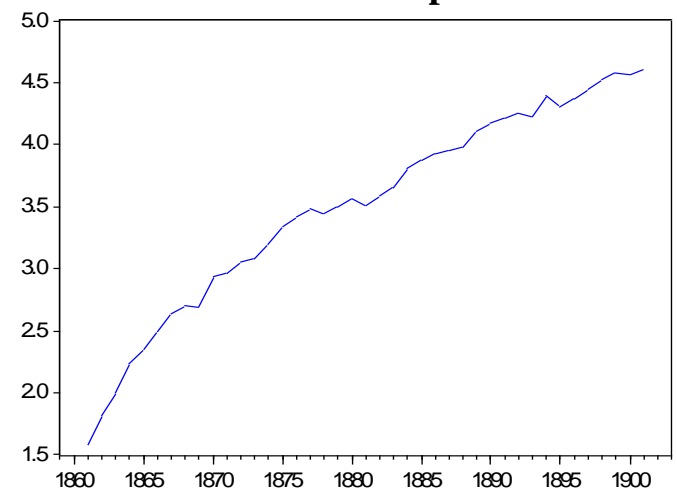

Figure 18: Log of Clothing and Textiles Patent Expenditure

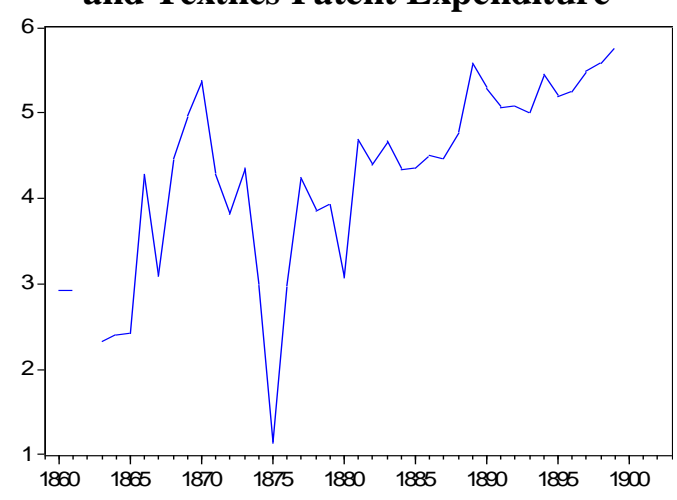


Figure 19: Log of

\section{Clothing Output}

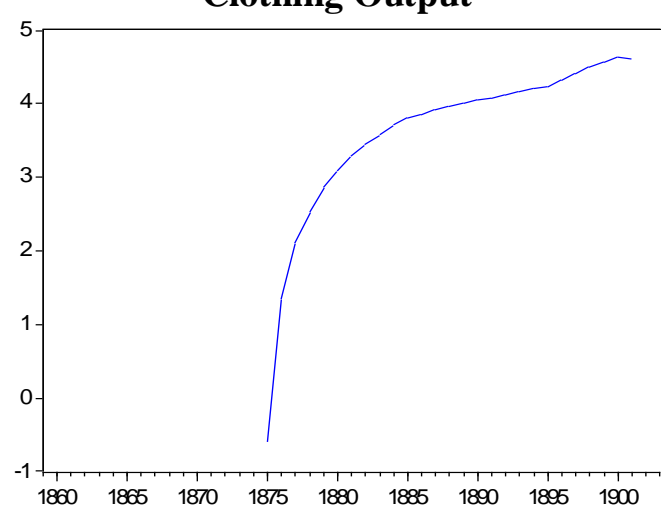

Figure 21: Log of Transport, Communications and Power Patent Expenditure

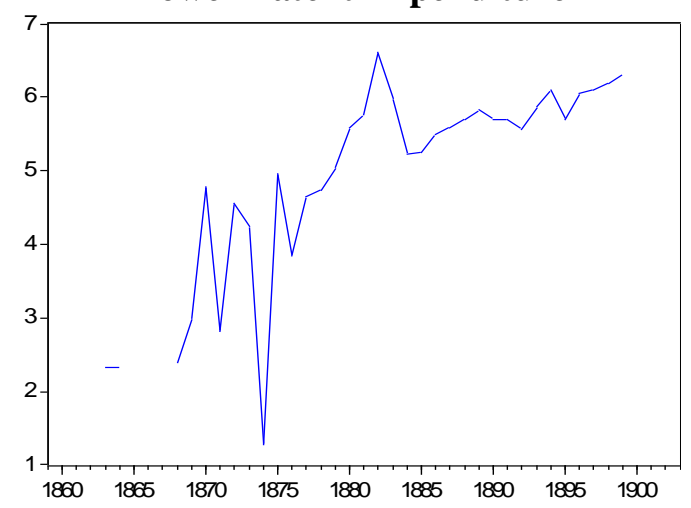

Figure 23: Log of Mining Patent Applications

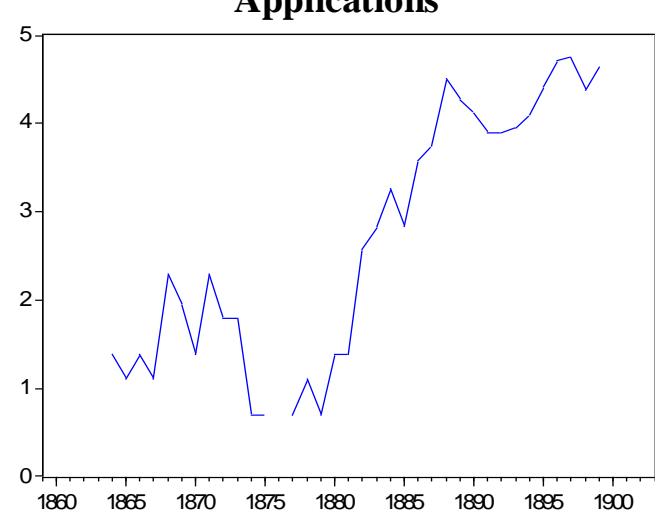

Figure 20: $\log$ of Transport, Communications, Power Applications

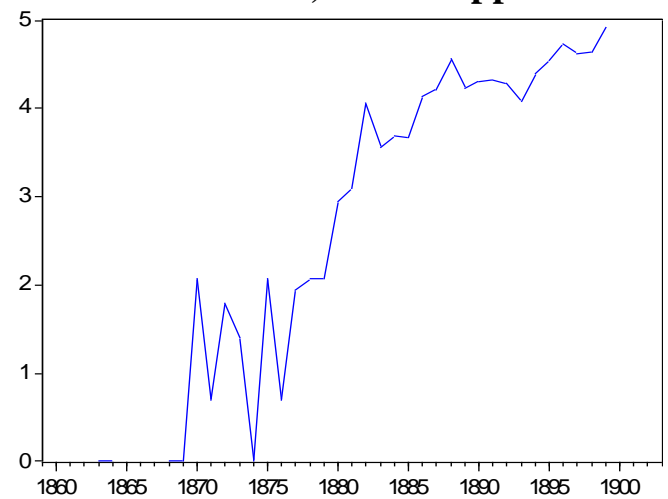

Figure 22: $\log$ of Manufacturing Output

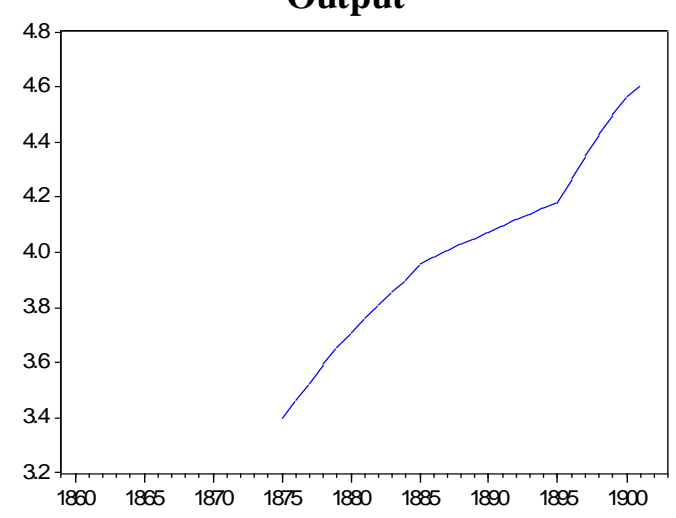

Figure 24: Log of Mining Patent Expenditure

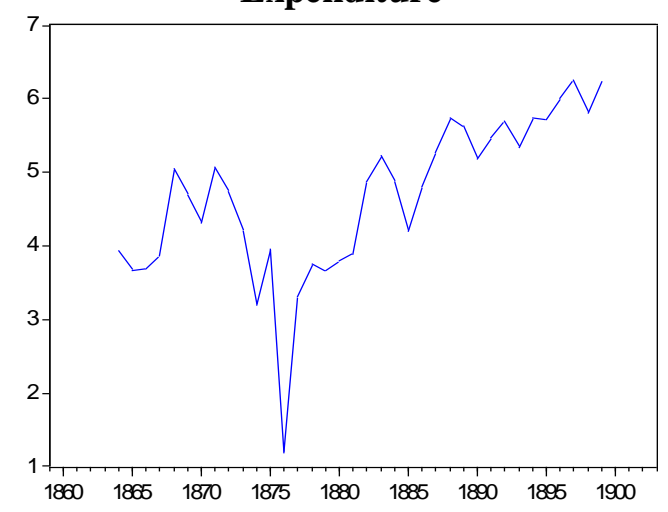


Figure 25: Log of Mining Output

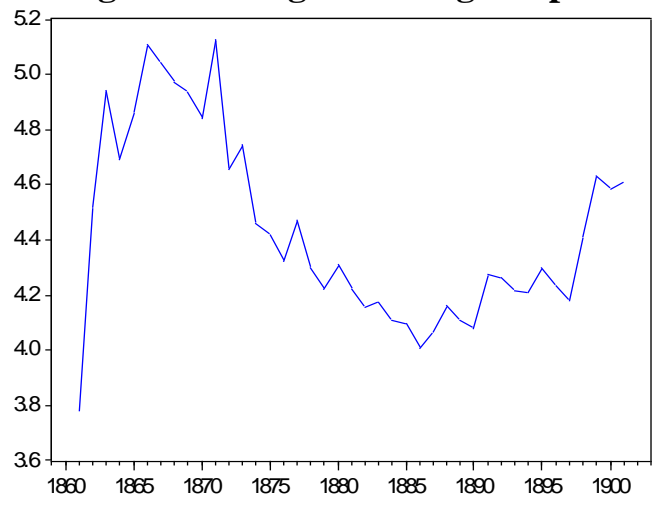

Figure 26: Log of Engineering Output

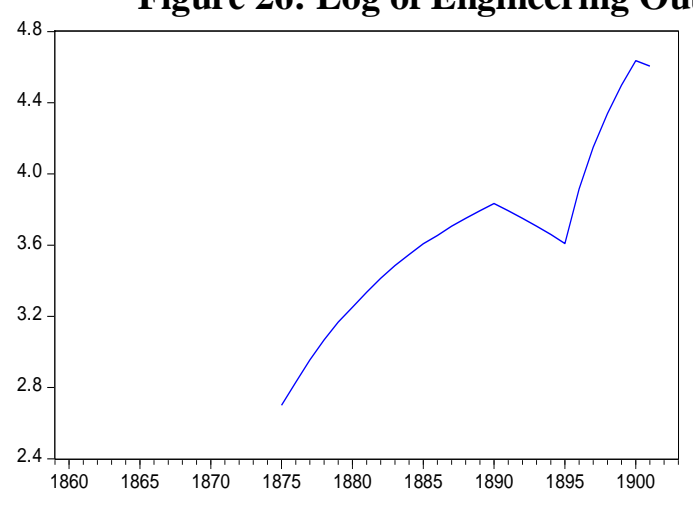

Tables 2 and 3 summarize the direction of Granger causality. The arrows indicate whether at a 5 percent level causality ran from patent applications to output and real GDP, or vice versa. Greasley and Oxley (2010, p. 452) tested pair-wise Granger causality between patent applications and output between 1871 and 1939, and found that the statistically significant relationships indicated that patenting usually led output. Over the earlier and shorter 1860-1899 period and using more summarized output data and total real GDP, this study finds the reverse. Indeed, applications Granger caused output and real GDP in four statistically significant causal linkages, while output and real GDP Granger caused patent applications in seven such linkages. For expenditure on patents, which Greasley and Oxley did not have data on; there were more statistically significant cases of Granger causality. Indeed, expenditure on patents Granger caused output and real GDP in four statistically significant causal linkages, while output and real GDP Granger caused expenditure in thirteen statistically significant causal linkages.

This indicates that over the period covered, and using summary data and real GDP, output and real GDP were more closely linked to expenditure on patents than to patent applications. Furthermore, output and real GDP usually seems to have led patenting, rather than vice versa. Researchers in other countries have also found that increased GDP, output or investment in a particular sector boosts patenting in that sector (Schmookler 1966, p.136, Khan and Sokoloff 1993, p.297, Magee 2000, p.111). This effect of output on patent applications was stronger for New Zealand than for foreign patent applicants, perhaps because the short-term economic situation in New Zealand had less effect on applications from overseas. 
Table 2: Patents Applications and Output and Real GDP:

Granger Causality

\begin{tabular}{|c|c|c|c|c|}
\hline \multirow[b]{2}{*}{$\begin{array}{l}\text { Patent application } \\
\text { variables }\end{array}$} & \multicolumn{4}{|c|}{$\begin{array}{l}\text { Output Variables and Real GDP } \\
\text { Two Year Lead for Granger causality } \\
\text { and Difference if Not Cointegrated }\end{array}$} \\
\hline & $\begin{array}{c}\text { Rankin } \\
\text { GDP real }\end{array}$ & $\begin{array}{l}\text { Agriculture } \\
\text { output }\end{array}$ & $\begin{array}{l}\text { Mining } \\
\text { output }\end{array}$ & $\begin{array}{c}\text { Pastoral } \\
\text { output }\end{array}$ \\
\hline Total applications & $<\neq>$ & $<\neq>$ & $<\neq>$ & $\Rightarrow$ \\
\hline NZ applications & $<=$ & $<=$ & $<\neq>$ & $\Rightarrow$ \\
\hline Foreign applications & $<\neq>$ & $<\neq>$ & $<\neq>$ & $\Leftrightarrow$ \\
\hline 14-year applications & $<\neq>$ & $<\neq>$ & $<\neq>$ & $<=$ \\
\hline Agriculture applications & $<\neq>$ & $<=$ & $<=$ & $<\neq>$ \\
\hline Clothing applications & $<\neq>$ & $<\neq>$ & $<\neq>$ & $<\neq>$ \\
\hline Transport, comms, power & $<\neq>$ & $<\neq>$ & $<\neq>$ & $<\neq>$ \\
\hline Mining applications & $<=$ & $<\neq>$ & $<\neq>$ & $\Rightarrow$ \\
\hline Pastoralism applications & $<\neq>$ & $<\neq>$ & $<\neq>$ & $<\neq>$ \\
\hline
\end{tabular}

\section{Notes}

At a 5\% level, =>indicates unidirectional causality from applications to output, $<=$ indicates causality from output to applications, $\Leftrightarrow$ indicates bidirectional causality, $<\notin>$ reveals no evidence in either direction.

Table 3: Expenditure on Patents and Output and Real GDP: Granger Causality Results

\begin{tabular}{lcccc}
\hline & \multicolumn{4}{c}{ Output Variables and Real GDP } \\
& \multicolumn{4}{c}{$\begin{array}{c}\text { Two Year Lead for Granger Causality } \\
\text { and Difference if Not Cointegrated }\end{array}$} \\
\cline { 2 - 5 } $\begin{array}{l}\text { Patent expenditure } \\
\text { variables }\end{array}$ & $\begin{array}{c}\text { Rankin } \\
\text { GDP Real }\end{array}$ & $\begin{array}{c}\text { Agriculture } \\
\text { Output }\end{array}$ & $\begin{array}{c}\text { Mining } \\
\text { Output }\end{array}$ & $\begin{array}{c}\text { Pastoral } \\
\text { Output }\end{array}$ \\
\cline { 2 - 5 } Total expenditure & $<\neq>$ & $<\neq>$ & $<\neq>$ & $<=$ \\
NZ expenditure & $<\neq>$ & $<\neq>$ & $<\neq>$ & $<=$ \\
Foreign expenditure & $<\neq>$ & $<\neq>$ & $<\neq>$ & $\Leftrightarrow$ \\
14-year expenditure & $<=$ & $<=$ & $<\neq>$ & $<=$ \\
Agriculture expenditure & $<\neq>$ & $=>$ & $<=$ & $<=$ \\
Clothing expenditure & $<\neq>$ & $<\neq>$ & $<\neq>$ & $<\neq>$ \\
Transport, comms, power & $<=$ & $<=$ & $<\neq>$ & $<=$ \\
Mining expenditure & $<\neq>$ & $<\neq>$ & $<\neq>$ & $=$ \\
Pastoralism expenditure & $\Leftrightarrow$ & $<\neq>$ & $<\neq>$ & $<=$ \\
\hline
\end{tabular}

\section{Notes}

At a $5 \%$ level, =>indicates unidirectional causality from expenditure to output, $<=$ indicates causality from output to expenditure, $\Leftrightarrow$ indicates bidirectional causality, $<\neq>$ reveals no evidence in either direction.

In the more detailed tables $\mathrm{A} 1$ and $\mathrm{A} 2$ in the appendix the top number for each row of patent data tests for causality from patents to output or real GDP, while the lower number tests for causality from output or real GDP to patents. For instance, the p-value for total 
patent applications Granger causing real GDP in Table A1 is a non-significant 0.4960, while the p-value for GDP Granger causing total applications is also non-significant at 0.6138. Some of the series are not cointegrated $(\mathrm{N}, \mathrm{N})$ using either the trace (denoted in the table by a $\mathrm{T}$ ) or maximum eigenvalue (E) test, which meant that they had to be differenced before conclusions could be drawn about relationships between the variables. Tables A1 and A2 also show coefficients where Granger causality existed. Usually mining output was not cointegrated with patent applications or expenditure variables. In addition, clothing patent applications and expenditure were not cointegrated with agriculture and mining output. However, output from the dominant pastoral sector was cointegrated with most patent expenditure variables.

The summary applications results in Table 2 show total applications, New Zealand applications, and foreign patent applications all Granger caused pastoral output. Table 3 shows the reverse is true for total and New Zealand expenditure on patents, although for expenditure on foreign patents the relationship is statistically significant in both directions. This indicates that the growth of the pastoral sector affected foreign patentees' expenditure on New Zealand patents, and that foreign patentees' expenditure was correlated with subsequent growth of pastoral output.

Although pastoralism patent applications did not Granger cause pastoral output, pastoral output Granger caused expenditure on pastoral patents. Expenditure on pastoral patents also Granger caused real GDP, while real GDP Granger caused expenditure on pastoral patents, suggesting linkages between invention in pastoralism and the economy as a whole. Agricultural output Granger caused agricultural patent applications, but the reverse was not true. Expenditure on agricultural patents, which includes patents on ploughs, sowing, threshing, reaping, and harvesting machines, Granger caused agriculture output. However, agricultural output did not Granger cause agricultural patent expenditure. These results suggest that expenditure on agricultural patents does not seem to have been responsive to short-term agricultural output, although the total number of agricultural patent applications filed was responsive to short-term agricultural output.

Sorting the data by individual inventors' expenditure on patents for each industry revealed that five of the top twenty inventors on this list were there because of their patents for agricultural inventions. Four of these patentees were New Zealanders who had founded successful agricultural technology firms (Gibbons and Oxley 2016). In contrast, a wider range of people patented specifically pastoral patents, which were often about fencing, hedges, and rabbit control, than protected agriculture inventions. Indeed, only one inventor (Frederik York Wolseley of New South Wales and Ireland, who patented sheep shearing machines) was on the top twenty inventors by industry expenditure list for pastoral sector inventions. Furthermore, whereas the ten highest spending agriculture patentees accounted for 17.6 percent of expenditure on agriculture patents, the top ten spending pastoralism 
patentees made only 8.0 percent of expenditure on pastoralism patents. Even restricting pastoralism to exclude dairying and refrigeration resulted in the top ten patentees of pastoral inventions accounting for only 12.0 percent of expenditure on such inventions. As discussed elsewhere, over the period covered, pastoralism appears to have attracted fewer professional inventors than agriculture (Gibbons and Oxley 2016).

Pastoral patents seem to have sometimes been responsive to more short-term pressures than agricultural patents, and sometimes had a lesser economic effect. However, looking at more detailed results in Appendix A, the coefficient for pastoralism applications Granger causing cheese output (Table A4) is significant, as it was for Greasley and Oxley (2010, p. 449 ), at a 5 percent level. Similarly, the coefficient for expenditure on pastoral patents Granger causing cheese output (Table A5) is almost significant at a 5 percent level, suggesting patent expenditure may have also boosted cheese output. A longer time-period would give clearer insights into this, particularly since the dairying industry was still small in 1899 , and the number of pastoralism patents specifically about dairying was low.

The level of GDP Granger caused mining patent applications, suggesting that investment in mining often reflected the state of the economy. Indeed, mining patent applications did not Granger cause mining output. Mining patent expenditure Granger caused pastoral output, although the coefficient was not significant. Because of the gold rushes, mining output followed different patterns to the other output series, justifying further analysis. Using percentage data for patents and for exports, which is inherently $\mathrm{I}(0)$, there was strong evidence (Table 4) that gold exports Granger caused mining patent applications and expenditure on mining patents. There was weaker evidence (Table A6) that mining patent applications Granger caused the percentage of exports that gold constituted.

Table 4: Percentage of Mining Patent Applications and Expenditure and Percentage of Gold Exports: Granger Causality

\footnotetext{
Gold Exports Percent (two year lag)

\begin{tabular}{ll}
\hline Mining patent applications $\%$ & $<=$ \\
Mining patent expenditure $\%$ & $<=$ \\
\hline Notes & $<$ At a $5 \%$ level, $=>$ indicates unidirectional causality from patents to exports, $<=$ indicates causality from \\
exports to patents, $\Leftrightarrow$ indicates bidirectional causality,$<\neq>$ reveals no evidence in either direction.
\end{tabular}

There were several linkages between output variables and real GDP with expenditure, but not applications, on patents relating to transport, communications and power. This suggests that economic prosperity increased investment in these areas. There was less evidence, even after considering a range of lags, that this investment in patents boosted output or real GDP.
} 
The relationship between applications and expenditure on patents that ran for 14 years and subsequent output and real GDP is different to the relationship between total patent applications and expenditure and subsequent output and real GDP. In particular, total applications Granger caused pastoral output, whereas pastoral output Granger caused applications for patents that ran for 14 years. However, output variables and real GDP were more likely to Granger cause expenditure on fourteen-year patents than on total patent expenditure. This is not surprising because of the high cost of taking out a patent for fourteen years. Although patents with a 14-year life are potentially of higher quality than other patents (Streb, Baten et al. 2006), over the period covered there was not a stronger relationship between these patents and subsequent output and real GDP than between all patents and subsequent output and real GDP.

\section{Conclusions}

This article has advanced the literature on patents and production by weighting patent applications in colonial New Zealand between 1860 and 1899 by expenditure on each patent. In particular, it tested whether the relationship between patenting and both economic output series and real GDP was different using data on fees and other required expenditure on patents, rather than just using the count of patent applications.

In contrast to Greasley and Oxley (2010, p.452), who covered a longer time period and just used output data, which included more disaggregated output series, output and real GDP Granger caused patent applications more often than applications Granger caused output and real GDP. The unique data on patenting expenditure used here also followed the same pattern, although Granger causality from output and real GDP to patents occurred considerably more frequently with patent expenditure data than with patents applications. As expenditure on patenting may be a more informative measure of the quality of the patent or its perceived economic value, this suggests that the expenditure data are more useful than just application count data for understanding the relationship between patenting and output and real GDP. Furthermore, output and real GDP seems to have more often caused patenting applications and expenditure than patenting caused economic output and real GDP. However, in some of the results patenting Granger caused output and real GDP, with the relationship between agricultural patent expenditure and agricultural output being an important example.

Because the results show a stronger relationship between patent applications weighted by expenditure on each patent than just applications, the results support studies that argue that quality measures should be use to weight patents applications (Sullivan 1994, Streb, Baten et al. 2006, Nuvolari and Tartari 2011). However, there was little evidence that 14-year patents were more important than patents that were not renewed. In contrast, there was some evidence that agriculture patents, which were disproportionately registered by important inventors (Gibbons and Oxley 2016), had a larger economic impact than pastoral patents. 


\section{References}

Auger, C.P. (1992). Information Sources on Patents. London: Bowker-Saur.

Boehm, K. (1967). The British Patent System: Administration. Cambridge: Cambridge University Press.

Cotter, R. (2006). Measuring New Zealand Inventiveness. Unpublished B.Com.(Hons), University of Canterbury.

Dutton, H.I. (1984). The Patent System and Inventive Activity During the Industrial Revolution, 17501852. Manchester: Manchester University Press.

Engle, R.F. and C.W.J. Granger (1987). Co-integration and error correction: Representation, estimation, and testing. Econometrica 55, pp. 251-276.

Evening Star (1889). Inventions and inventors. Dunedin, 16 May, p. 1.

Gibbons, M. and L. Oxley (2016). The democratisation of patenting in New Zealand, 1860-1899. Hamilton: University of Waikato.

Gibbons, M. and L. Oxley (2016). Great nineteenth century New Zealand inventors. Hamilton: University of Waikato.

Greasley, D. and L. Oxley (2007). Patenting, intellectual property rights and sectoral outputs in industrial revolution Britain, 1780-1851. Journal of Econometrics 139, pp. 340-354.

Greasley, D. and L. Oxley (2010). Cliometrics and time series econometrics: Some theory and applications. Journal of Economic Surveys 24, pp. 970-1042.

Greasley, D. and L. Oxley (2010). Knowledge, natural resource abundance and economic development: Lessons from New Zealand 1861-1939. Explorations in Economic History 47, pp. 443-459.

Greenshields, W. (1887). The following information concerning British and colonial patents. New Zealand Herald, 2 March, p. 4.

Griliches, Z. (1998). Patent statistics as economic indicators: a survey. In Z. Griliches (ed), $R \& D$ and Productivity: The Econometric Evidence. Chicago, IL: University of Chicago Press.

Hanlon, W.W. (2015). Necessity is the mother of invention: Input supplies and directed technical change. Econometrica 83, pp. 67-100.

Hansen, B.E. (2001). The new econometrics of structural change: Dating breaks in U.S. labor productivity. Journal of Economic Perspectives 15, pp. 117-128. 
Khan, B.Z. and K.L. Sokoloff (1993). "Schemes of Practical Utility": Entrepreneurship and Innovation Among "Great Inventors" in the United States, 1790-1865. The Journal of Economic History 53, pp. 289-307.

MacLeod, C., J. Tann, J. Andrew and J. Stein (2003). Evaluating inventive activity: The cost of nineteenth-century UK patents and the fallibility of renewal data. The Economic History Review 56, pp. 537-562.

Magee, G.B. (2000). Knowledge Generation: Technological Change and Economic Growth in Colonial Australia. Melbourne: Australian Scholarly Publishing.

Nelson, C.R. and C.R. Plosser (1982). Trends and random walks in macroeconomic time series: Some evidence and implications. Journal of Monetary Economics 10, pp. 139-162.

Nuvolari, A. and V. Tartari (2011). Bennet Woodcroft and the value of English patents, 1617-1841. Explorations in Economic History 48, pp.97-115.

Perron, P. (1989). The great crash, the oil price shock, and the unit root hypothesis. Econometrica 57, pp. 1361-1401.

Rankin, K. (1992). New Zealand's Gross National Product: 1859-1939. The Review of Income and Wealth 38, pp. 49-69.

Schankerman, M. and A. Pakes (1986). Estimates of the value of patent rights in European countries during the post-1950 period. The Economic Journal 96, pp. 1052-1076.

Schmookler, J. (1966). Invention and Economic Growth. Cambridge, M.A.: Harvard University Press.

Streb, J., J. Baten and S. Yin (2006). Technological and geographical knowledge spillover in the German empire 1877-1918. The Economic History Review 59, pp. 347-373.

Sullivan, R.J. (1994). Estimates of the value of patent rights in Great Britain and Ireland, 1852- 1876. Economica 61, pp. 37-58.

Williams, R. and L. Oxley (2016). The geography of inventiveness in the primary sector: Some initial results for New Zealand, 1880-1895. Australian Economic History Review 56, pp. 151-173. 
Table A1: The Relationship between Patent Applications, Output Series and Real GDP:

Cointegration, Granger Causality and Selected Coefficients

\begin{tabular}{|c|c|c|c|c|c|c|c|c|c|c|c|c|}
\hline \multirow{4}{*}{$\begin{array}{l}\text { Patent application } \\
\text { variables (difference } \\
\text { if CR is NN) } \\
\text { Total applications }\end{array}$} & \multicolumn{12}{|c|}{$\begin{array}{l}\text { Output Variables and Real GDP } \\
\text { Two Year Lead for Granger Causality and Difference if Not Cointegrated }\end{array}$} \\
\hline & \multicolumn{3}{|c|}{ Rankin GDP real } & \multicolumn{3}{|c|}{ Agriculture output } & \multicolumn{3}{|c|}{ Mining output } & \multicolumn{3}{|c|}{ Pastoral output } \\
\hline & $\begin{array}{l}\text { CR } \\
\text { (model, } \\
\text { lag) }\end{array}$ & GC & $\begin{array}{l}\text { Coeff if } \\
\text { causal }\end{array}$ & $\begin{array}{l}\text { CR } \\
\text { (model, } \\
\text { lag) }\end{array}$ & GC & $\begin{array}{l}\text { Coeff if } \\
\text { causal }\end{array}$ & $\begin{array}{l}\text { CR } \\
\text { (model, } \\
\text { lag) }\end{array}$ & GC & $\begin{array}{l}\text { Coeff if } \\
\text { causal }\end{array}$ & $\begin{array}{l}\text { CR } \\
\text { (model, } \\
\text { lag) }\end{array}$ & GC & $\begin{array}{l}\text { Coeff if } \\
\text { causal }\end{array}$ \\
\hline & $\mathrm{TE}(3,1)$ & $\begin{array}{l}0.4960 \\
0.6138\end{array}$ & & $\mathrm{~T}, \mathrm{E}(2,1)$ & $\begin{array}{l}0.7047 \\
0.1754\end{array}$ & & $\mathrm{~N}, \mathrm{~N}$ & $\begin{array}{l}0.9320 \\
0.2609\end{array}$ & & $\mathrm{~T}, \mathrm{E}(3,1)$ & $\begin{array}{l}\mathbf{0 . 0 0 3 0} \\
0.4602\end{array}$ & $0.28(0.03)$ \\
\hline $\mathrm{NZ}$ applications & $\begin{array}{l}2 \mathrm{~T}, 2 \mathrm{E},(3, \\
3)\end{array}$ & $\begin{array}{l}0.1378 \\
\mathbf{0 . 0 2 1 0}\end{array}$ & $1.63(0.59)$ & $\mathrm{T}, \mathrm{N}(2,1)$ & $\begin{array}{l}0.7131 \\
\mathbf{0 . 0 2 9 7}\end{array}$ & $1.74(0.77)$ & $\mathrm{N}, \mathrm{N}$ & $\begin{array}{l}0.9234 \\
0.1467\end{array}$ & & $\mathrm{~T}, \mathrm{E}(3,1)$ & $\begin{array}{l}\mathbf{0 . 0 2 0 1} \\
0.2496\end{array}$ & $0.27(0.03)$ \\
\hline Foreign applications & $\mathrm{T}, \mathrm{E}(3,3)$ & $\begin{array}{l}0.3714 \\
0.0965\end{array}$ & & $\mathrm{~T}, \mathrm{~N}(2,1)$ & $\begin{array}{l}0.7724 \\
0.8992\end{array}$ & & $\mathrm{~N}, \mathrm{~N}$ & $\begin{array}{l}0.6843 \\
0.8441\end{array}$ & & $\mathrm{~T}, \mathrm{E}(3,1)$ & $\begin{array}{l}0.0031 \\
0.0330\end{array}$ & $\begin{array}{l}0.32(0.03) \\
3.07(0.23)\end{array}$ \\
\hline $\begin{array}{l}\text { 14-year patent } \\
\text { applications }\end{array}$ & $\mathrm{T}, \mathrm{E}(3,3)$ & $\begin{array}{l}0.6562 \\
0.0554\end{array}$ & & $\mathrm{~T}, \mathrm{~N}(1,1)$ & $\begin{array}{l}0.0834 \\
0.0585\end{array}$ & & $\mathrm{~N}, \mathrm{~N}$ & $\begin{array}{l}0.0834 \\
0.0585\end{array}$ & & $\begin{array}{l}2 \mathrm{~T}, 2 \mathrm{E} \\
(3,1)\end{array}$ & $\begin{array}{l}0.1888 \\
\mathbf{0 . 0 1 9 5}\end{array}$ & $-3.71(1.00)$ \\
\hline $\begin{array}{l}\text { Agriculture } \\
\text { applications }\end{array}$ & $\begin{array}{l}2 \mathrm{~T}, 2 \mathrm{E} \\
(3.2)\end{array}$ & $\begin{array}{l}0.6074 \\
0.3685\end{array}$ & & $\begin{array}{l}\mathrm{T}, \mathrm{N} \\
(3,2)\end{array}$ & $\begin{array}{l}0.3643 \\
\mathbf{0 . 0 4 6 6}\end{array}$ & $3.84(0.53)$ & $\mathrm{T}, \mathrm{E}(5,1)$ & $\begin{array}{l}0.4420 \\
\mathbf{0 . 0 0 0 1}\end{array}$ & $-3.19(0.60)$ & $\mathrm{T}, \mathrm{E}(2,1)$ & $\begin{array}{l}0.6376 \\
0.5524\end{array}$ & \\
\hline $\begin{array}{l}\text { Clothing } \\
\text { applications }\end{array}$ & $\begin{array}{l}2 \mathrm{~T}, 2 \mathrm{E} \\
(3,2)\end{array}$ & $\begin{array}{l}0.1061 \\
0.2960\end{array}$ & & $\mathrm{~N}, \mathrm{~N}$ & $\begin{array}{l}0.7243 \\
0.9554\end{array}$ & & $\mathrm{~N}, \mathrm{~N}$ & $\begin{array}{l}0.9576 \\
0.4456\end{array}$ & & $\mathrm{~T}, \mathrm{E}(2,2)$ & $\begin{array}{l}0.1165 \\
0.8060\end{array}$ & \\
\hline $\begin{array}{l}\text { Transport, comms, } \\
\text { power applications }\end{array}$ & $\begin{array}{l}2 \mathrm{~T}, 2 \mathrm{E} \\
(3.2)\end{array}$ & $\begin{array}{l}0.3372 \\
0.0615\end{array}$ & & $\mathrm{~T}, \mathrm{~N}(2,2)$ & $\begin{array}{l}0.9745 \\
0.6530\end{array}$ & & $\mathrm{~T}, \mathrm{E}(2,2)$ & $\begin{array}{l}0.4846 \\
0.2506\end{array}$ & & $\mathrm{~T}, \mathrm{E}(2,1)$ & $\begin{array}{l}0.1680 \\
0.8020\end{array}$ & \\
\hline Mining applications & $\mathrm{T}, \mathrm{E}(1,2)$ & $\begin{array}{l}0.6620 \\
\mathbf{0 . 0 1 6 4}\end{array}$ & $1.21(0.11)$ & $\mathrm{N}, \mathrm{N}$ & $\begin{array}{l}0.8806 \\
0.3536\end{array}$ & & $\begin{array}{l}2 \mathrm{~T}, \mathrm{~N} \\
(3,2)\end{array}$ & $\begin{array}{l}0.5047 \\
0.4457\end{array}$ & & $\mathrm{~T}, \mathrm{E}(2,1)$ & $\begin{array}{l}\mathbf{0 . 0 2 4 0} \\
0.2944\end{array}$ & $0.31(0.08)$ \\
\hline $\begin{array}{l}\text { Pastoralism } \\
\text { applications }\end{array}$ & $\begin{array}{l}2 \mathrm{~T}, 2 \mathrm{E} \\
(3,2)\end{array}$ & $\begin{array}{l}0.3072 \\
0.1098\end{array}$ & & $\begin{array}{l}2 \mathrm{~T}, 2 \mathrm{E} \\
(3,2)\end{array}$ & $\begin{array}{l}0.2398 \\
0.5844\end{array}$ & & $\mathrm{~T}, \mathrm{~N}(2,3)$ & $\begin{array}{l}0.8087 \\
0.2135\end{array}$ & & $\mathrm{~T}, \mathrm{E}(2,1)$ & $\begin{array}{l}0.3872 \\
0.1453\end{array}$ & \\
\hline
\end{tabular}

Notes

The top statistics for Granger causality for each row of applications data tests for causality from patents; the lower number tests the reverse. Bold values have a p-value of 0.05 or less and are considered significant. 
Table A2: The Relationship between Expenditure on Patents and Output Series and Real GDP:

Cointegration and Granger Causality Results

\begin{tabular}{|c|c|c|c|c|c|c|c|c|c|c|c|c|}
\hline \multirow[b]{3}{*}{$\begin{array}{l}\text { Patent expenditure } \\
\text { variables }\end{array}$} & \multicolumn{12}{|c|}{$\begin{array}{c}\text { Output variables and Real GDP } \\
\text { Two Year Lead and Difference if Not Cointegrated }\end{array}$} \\
\hline & \multicolumn{3}{|c|}{ Rankin GDP Real } & \multicolumn{3}{|c|}{ Agriculture Output } & \multicolumn{3}{|c|}{ Mining Output } & \multicolumn{3}{|c|}{ Pastoral Output } \\
\hline & $\begin{array}{l}\text { CR (model, } \\
\text { lag) }\end{array}$ & $\mathrm{GC}$ & $\begin{array}{l}\text { Coeff if } \\
\text { causal }\end{array}$ & $\begin{array}{l}\text { CR (model, } \\
\text { lag) }\end{array}$ & GC & $\begin{array}{l}\text { Coeff if } \\
\text { causal }\end{array}$ & $\begin{array}{l}\mathrm{CR} \\
\text { (model, } \\
\text { lag) }\end{array}$ & $\mathrm{GC}$ & $\begin{array}{l}\text { Coeff if } \\
\text { causal }\end{array}$ & $\begin{array}{l}\text { CR } \\
\text { (model, } \\
\text { lag) }\end{array}$ & GC & $\begin{array}{l}\text { Coeff if } \\
\text { causal }\end{array}$ \\
\hline Total expenditure & $2 \mathrm{~T}, \mathrm{~N}(3,1)$ & $\begin{array}{l}0.3989 \\
0.1506\end{array}$ & & $2 \mathrm{~T}, 2 \mathrm{E}(5,1)$ & $\begin{array}{l}0.1362 \\
0.1108\end{array}$ & & $\mathrm{~T}, \mathrm{E}(5,1)$ & $\begin{array}{l}0.2847 \\
0.5691\end{array}$ & & $\begin{array}{l}2 \mathrm{~T}, 2 \mathrm{E} \\
(3,1)\end{array}$ & $\begin{array}{l}0.1391 \\
0.0068\end{array}$ & $0.66(0.23)$ \\
\hline NZ expenditure & $2 \mathrm{~T}, \mathrm{~N}(3,3)$ & $\begin{array}{l}0.0617 \\
0.9341\end{array}$ & & $\mathrm{~T}, \mathrm{E}(2,2)$ & $\begin{array}{l}0.5105 \\
0.7694\end{array}$ & & $\begin{array}{l}\mathrm{N}, \mathrm{N}(5, \\
1)\end{array}$ & $\begin{array}{l}0.5256 \\
0.5238\end{array}$ & & $\begin{array}{l}2 \mathrm{~T}, 2 \mathrm{E} \\
(3,1)\end{array}$ & $\begin{array}{l}0.6177 \\
\mathbf{0 . 0 0 4 8}\end{array}$ & $1.32(0.12)$ \\
\hline Foreign expenditure & $\mathrm{T}, \mathrm{E}(3,3)$ & $\begin{array}{l}0.1141 \\
0.7048\end{array}$ & & $\mathrm{~T}, \mathrm{E}(3,3)$ & $\begin{array}{l}0.6949 \\
0.9548\end{array}$ & & $\mathrm{~N}, \mathrm{~N}(5,1)$ & $\begin{array}{l}0.8080 \\
0.7724\end{array}$ & & $\begin{array}{l}2 \mathrm{~T}, 2 \mathrm{E} \\
(3.1)\end{array}$ & $\begin{array}{l}0.0186 \\
0.0026\end{array}$ & $\begin{array}{l}0.37(0.06) \\
2.66(0.25)\end{array}$ \\
\hline $\begin{array}{l}\text { 14-year patent } \\
\text { expenditure }\end{array}$ & $2 \mathrm{~T}, 2 \mathrm{E}(3,3)$ & $\begin{array}{l}0.3180 \\
\mathbf{0 . 0 1 7 1}\end{array}$ & $1.02(0.14)$ & $2 \mathrm{~T}, 2 \mathrm{E}(3,1)$ & $\begin{array}{l}0.6194 \\
\mathbf{0 . 0 1 7 4}\end{array}$ & $1.12(0.10)$ & $\mathrm{N}, \mathrm{N}(5,1)$ & $\begin{array}{l}0.5911 \\
0.4653\end{array}$ & & $\begin{array}{l}2 \mathrm{~T}, 2 \mathrm{E} \\
(3,2)\end{array}$ & $\begin{array}{l}0.4965 \\
\mathbf{0 . 0 0 0 8}\end{array}$ & $0.21(0.21)$ \\
\hline $\begin{array}{l}\text { Agriculture } \\
\text { expenditure }\end{array}$ & $2 \mathrm{~T}, 2 \mathrm{E}(3,2)$ & $\begin{array}{l}0.9384 \\
0.0611\end{array}$ & & $2 \mathrm{~T}, \mathrm{~N}(3,3)$ & $\begin{array}{l}\mathbf{0 . 0 3 2 4} \\
0.1504\end{array}$ & $2.06(0.50)$ & $\mathrm{T}, \mathrm{E}(5,1)$ & $\begin{array}{l}0.2138 \\
\mathbf{0 . 0 0 0 0}\end{array}$ & $-2.07(0.46)$ & $\mathrm{T}, \mathrm{E}(3,3)$ & $\begin{array}{l}0.8993 \\
\mathbf{0 . 0 3 9 4}\end{array}$ & $1.36(0.23)$ \\
\hline Clothing expend & $2 \mathrm{~T}, 2 \mathrm{E}(3,2)$ & $\begin{array}{l}0.6097 \\
0.9058\end{array}$ & & $\mathrm{~N}, \mathrm{~N}$ & $\begin{array}{l}0.4812 \\
0.8183\end{array}$ & & $\mathrm{~N}, \mathrm{~N}(1,1)$ & $\begin{array}{l}0.5462 \\
0.2082\end{array}$ & & $\begin{array}{l}2 \mathrm{~T}, \mathrm{~N} \\
(5,1)\end{array}$ & $\begin{array}{l}0.7353 \\
0.1793\end{array}$ & \\
\hline $\begin{array}{l}\text { Transport, comms, } \\
\text { power expenditure }\end{array}$ & $2 \mathrm{~T}, 2 \mathrm{E}(3,1)$ & $\begin{array}{l}0.2349 \\
\mathbf{0 . 0 0 9 8}\end{array}$ & $1.68(0.40)$ & $\mathrm{T}, \mathrm{E}(3,1)$ & $\begin{array}{l}0.3428 \\
\mathbf{0 . 0 0 9 2}\end{array}$ & $2.16(0.21)$ & $\mathrm{T}, \mathrm{E}(1,2)$ & $\begin{array}{l}0.2150 \\
0.0907\end{array}$ & & $\begin{array}{l}2 \mathrm{~T}, 2 \mathrm{E} \\
(3,0)\end{array}$ & $\begin{array}{l}0.5753 \\
\mathbf{0 . 0 4 5 6}\end{array}$ & $1.59(0.24)$ \\
\hline Mining expenditure & $\mathrm{T}, \mathrm{E}(2,2)$ & $\begin{array}{l}0.0599 \\
0.1787\end{array}$ & & $\mathrm{~T}, \mathrm{E}(5,3)$ & $\begin{array}{l}0.4347 \\
0.8637\end{array}$ & & $\mathrm{~N}, \mathrm{~N}(1,1)$ & $\begin{array}{l}0.5274 \\
0.7876\end{array}$ & & $\begin{array}{l}2 \mathrm{~T}, \mathrm{~N} \\
(5,1)\end{array}$ & $\begin{array}{l}\mathbf{0 . 0 0 9 5} \\
0.3196\end{array}$ & $-0.04(0.03)$ \\
\hline $\begin{array}{l}\text { Pastoralism } \\
\text { expenditure }\end{array}$ & $2 \mathrm{~T}, 2 \mathrm{E}(3,1)$ & $\begin{array}{l}0.0451 \\
0.0283\end{array}$ & $\begin{array}{l}0.16(0.03) \\
6.18(0.72)\end{array}$ & $\mathrm{T}, \mathrm{E}(2,2)$ & $\begin{array}{l}0.7372 \\
0.4821\end{array}$ & & $\begin{array}{l}2 \mathrm{~T}, \mathrm{~N} \\
(3,2)\end{array}$ & $\begin{array}{l}0.5298 \\
0.1445\end{array}$ & & $\begin{array}{l}\mathrm{T}, \mathrm{E} \\
(3,2)\end{array}$ & $\begin{array}{l}0.8283 \\
\mathbf{0 . 0 3 3 5}\end{array}$ & $1.51(0.09)$ \\
\hline
\end{tabular}

Notes

The top statistics for Granger causality for each row of expenditure data tests for causality from patents, the lower number tests for the reverse. Bold values have a p-value of 0.05 or less and are considered significant 


\section{Detailed Pastoral Sector Results}

Unit root test results, cointegration, and Granger causality results for selected pastoral sector output series show that pastoral patent applications Granger cause cheese output. Furthermore, there is some evidence (at a 6.7 percent level) that expenditure on pastoral patents Granger caused cheese output.

Table A.3: Unit Root Test Results using Modified Hannan-Quinn Criterionfor Pastoral Output Series

\begin{tabular}{lccccc}
\hline \multicolumn{7}{c}{ Ln Output } \\
\hline Variable (in logs) & I & Lags & Equation & ADF & P-value \\
\hline Meat & 1 & 9 & I,T & -6.35 & 0 \\
Butter & 0 & 9 & I,T & -4.31 & 0.01 \\
Cheese & 1 & 9 & I & -7.93 & 0 \\
Wool & 1 & 9 & I,T & -3.65 & 0.01 \\
\hline Note
\end{tabular}

Note

I=intercept, $\mathrm{T}=$ trend 
Table A4: Patents Applications and Selected Pastoralism Output Series: Cointegration, Granger Causality and Selected Coefficients

\begin{tabular}{|c|c|c|c|c|c|c|c|c|c|}
\hline \multirow{4}{*}{$\begin{array}{l}\text { Patent Application } \\
\text { Variables } \\
\text { (Difference if CR } \\
\text { is NN) } \\
\text { Total applications }\end{array}$} & \multicolumn{9}{|c|}{$\begin{array}{l}\text { Output Variables } \\
\text { Two Year Lead for Granger Causality and Difference if Not Cointegrated }\end{array}$} \\
\hline & \multicolumn{3}{|c|}{ Meat Output } & \multicolumn{3}{|c|}{ Wool Output } & \multicolumn{3}{|c|}{ Cheese Output } \\
\hline & $\begin{array}{c}\mathrm{CR} \\
\text { (option, lag) }\end{array}$ & $\mathrm{GC}$ & $\begin{array}{c}\text { Coeff } \\
\text { if causal } \\
\text { significant }\end{array}$ & $\begin{array}{c}\text { CR } \\
\text { (option, lag) }\end{array}$ & $\mathrm{GC}$ & $\begin{array}{c}\text { Coeff } \\
\text { if causal } \\
\text { significant }\end{array}$ & $\begin{array}{c}\text { CR } \\
\text { (option, lag) }\end{array}$ & GC & $\begin{array}{c}\text { Coeff } \\
\text { if causal } \\
\text { significant }\end{array}$ \\
\hline & $\mathrm{T}, \mathrm{E}(2,1)$ & 0.1460 & & $\mathrm{~T}, \mathrm{E}(23,2)$ & 0.0090 & $0.23(0.03)$ & $\mathrm{T}, \mathrm{E}(1,2)$ & 0.0850 & \\
\hline & & 0.3589 & & & 0.5585 & & & 0.8470 & \\
\hline \multirow[t]{2}{*}{ NZ applications } & $\mathrm{T}, \mathrm{E}(2,1)$ & 0.2897 & & $\mathrm{~T}, \mathrm{E}(3,1)$ & 0.0474 & $0.21(0.04)$ & $\mathrm{T}, \mathrm{E}(2,2)$ & 0.0307 & $0.43(0.05)$ \\
\hline & & 0.0970 & & & 0.2843 & & & 0.7750 & \\
\hline Foreign & $\mathrm{T}, \mathrm{E}(2,1)$ & 0.1093 & & $2 \mathrm{~T}, 2 \mathrm{E}(3,2)$ & 0.0075 & $0.20(0.04)$ & $\mathrm{T}, \mathrm{E}(2,2)$ & 0.2291 & \\
\hline applications & & 0.0308 & $2 . .26(0.43)$ & & 0.0712 & & & 0.1868 & \\
\hline 14-year patent & $2 \mathrm{~T}, 2 \mathrm{E}(1,1)$ & 0.0378 & $2.07(0.20)$ & $2 \mathrm{~T}, 2 \mathrm{E}(3,2)$ & 0.1964 & & $\mathrm{~T}, \mathrm{E}(2,2)$ & 0.4290 & \\
\hline applications & & 0.0729 & & & 0.0449 & $-1.51(0.65)$ & & 0.4033 & \\
\hline applications & & 0.9892 & & & 0.3951 & & & 0.5241 & \\
\hline Clothing & $\mathrm{T}, \mathrm{E}(1,1)$ & 0.6296 & & $\mathrm{~T}, \mathrm{E}(3,1)$ & 0.0787 & & $\mathrm{~T}, \mathrm{E}(2,2)$ & 0.1920 & \\
\hline applications & & 0.1595 & & & 0.5240 & & & 0.2340 & \\
\hline Transport, comms, & $\mathrm{T}, \mathrm{E}(2,1)$ & 0.2623 & & $\mathrm{~T}, \mathrm{E}(2,2)$ & 0.2562 & & $\mathrm{~T}, \mathrm{E}(2,2)$ & 0.2301 & \\
\hline power applications & & 0.0947 & & & 0.3462 & & & 0.4234 & \\
\hline Mining & $\mathrm{T}, \mathrm{E}(1,1)$ & 0.6428 & & $\mathrm{~T}, \mathrm{~N}(3,2)$ & 0.0239 & $0.31(0.06)$ & $\mathrm{T}, \mathrm{N}(2,2)$ & 0.4071 & \\
\hline applications & & 0.0501 & & & 0.3443 & & & 0.3534 & \\
\hline Pastoralism & $\mathrm{T}, \mathrm{E}(1,1)$ & 0.2964 & & $\mathrm{~T}, \mathrm{E}(2,1)$ & 0.2293 & & $\mathrm{~T}, \mathrm{E}(5,1)$ & 0.0099 & $0.11(0.04)$ \\
\hline applications & & 0.5827 & & & 0.4198 & & & 0.4297 & \\
\hline
\end{tabular}

The top statistics for Granger causality for each row of applications data tests for causality from patents, the lower number tests for the reverse. 
Table A5: Expenditure on Patents and Selected Pastoralism Output Series: Cointegration and Granger Causality Results

\begin{tabular}{|c|c|c|c|c|c|c|c|c|c|}
\hline \multirow[b]{3}{*}{$\begin{array}{l}\text { Patent Expenditure } \\
\text { Variables }\end{array}$} & \multicolumn{9}{|c|}{$\begin{array}{c}\text { Output Variables } \\
\text { Two Year Lead and Difference if Not Cointegrated }\end{array}$} \\
\hline & \multicolumn{3}{|c|}{ Meat Output } & \multicolumn{3}{|c|}{ Wool Output } & \multicolumn{3}{|c|}{ Cheese Output } \\
\hline & $\begin{array}{c}\text { CR } \\
\text { (option, lag) }\end{array}$ & GC & $\begin{array}{c}\text { Coeff } \\
\text { if causal } \\
\text { significant } \\
\end{array}$ & $\begin{array}{c}\mathrm{CR} \\
\text { (option, lag) }\end{array}$ & $\mathrm{GC}$ & $\begin{array}{c}\text { Coeff if } \\
\text { causal } \\
\text { significant }\end{array}$ & $\begin{array}{c}\text { CR (option, } \\
\text { lag) }\end{array}$ & GC & $\begin{array}{c}\text { Coeff } \\
\text { if causal } \\
\text { significant } \\
\end{array}$ \\
\hline \multirow[t]{2}{*}{ Total expenditure } & $\mathrm{T}, \mathrm{E}(2,1)$ & 0.2570 & & $2 \mathrm{~T}, 2 \mathrm{E}(3,2)$ & 0.0848 & & $\mathrm{~T}, \mathrm{E}(1,2)$ & 0.5556 & \\
\hline & & 0.0032 & $1.06(0.36)$ & & 0.0445 & $2.74(0.31)$ & & 0.0673 & \\
\hline \multirow[t]{2}{*}{ NZ expenditure } & $2 \mathrm{~T}, 2 \mathrm{E}(2,1)$ & 0.7907 & & $2 \mathrm{~T}, 2 \mathrm{E}(3,1)$ & 0.6294 & & $\mathrm{~T}, \mathrm{E}(3,4)$ & 0.4799 & \\
\hline & & 0.0153 & $1.18(0.31)$ & & 0.0063 & $1.54(0.13)$ & & 0.0506 & \\
\hline \multirow[t]{2}{*}{ Foreign expenditure } & $2 \mathrm{~T}, 2 \mathrm{E}(1,2)$ & 0.0477 & $0.86(0.08)$ & $2 \mathrm{~T}, 2 \mathrm{E}(3,2)$ & 0.0241 & $-0.20(0.14)$ & $\mathrm{T}, \mathrm{E}(2,2)$ & 0.3549 & \\
\hline & & 0.0001 & $1.15(0.17)$ & & 0.0148 & $-4.96(1.45)$ & & 0.1456 & \\
\hline \multirow{2}{*}{$\begin{array}{l}\text { 14-year patent } \\
\text { expenditure }\end{array}$} & $\mathrm{T}, \mathrm{E}(1,2)$ & 0.2700 & & $\mathrm{~T}, \mathrm{E}(3,2)$ & 0.5817 & & $\mathrm{~T}, \mathrm{E}(2,2)$ & 0.5160 & \\
\hline & & 0.0048 & $0.85(0.22)$ & & 0.0028 & $0.00(0.24)$ & & 0.2029 & \\
\hline \multirow{2}{*}{$\begin{array}{l}\text { Agriculture } \\
\text { expenditure }\end{array}$} & $\mathrm{T}, \mathrm{E}(2,1)$ & 0.9227 & & $\mathrm{~T}, \mathrm{E}(3,3)$ & 0.5581 & & $\mathrm{~T}, \mathrm{E}(3,3)$ & 0.9859 & \\
\hline & & 0.0741 & & & 0.0377 & $1.59(0.26)$ & & 0.0997 & \\
\hline Clothing expend & $\mathrm{T}, \mathrm{E}(2,2)$ & 0.6173 & & $\mathrm{~T}, \mathrm{E}(4,1)$ & 0.7599 & & $\mathrm{~T}, \mathrm{E}(2,2)$ & 0.5552 & \\
\hline \multirow{4}{*}{$\begin{array}{l}\text { Transport, comms, } \\
\text { power expenditure } \\
\text { Mining expenditure }\end{array}$} & $\mathrm{T}, \mathrm{E}(2,2)$ & 0.6766 & & $\mathrm{~T}, \mathrm{E}(4,1)$ & 0.7344 & & $\mathrm{~T}, \mathrm{E}(1,2)$ & 0.6199 & \\
\hline & & 0.0122 & $7.83(5.41)$ & & 0.0598 & & & 0.1528 & \\
\hline & $\mathrm{T}, \mathrm{E}(1,2)$ & 0.2656 & & $\mathrm{~T}, \mathrm{~N}(3,1)$ & 0.0165 & $0.34(0.12)$ & $\mathrm{T}, \mathrm{E}(1,2)$ & 0.5284 & \\
\hline & & 0.0117 & $-3.97(1.48)$ & & 0.3985 & & & 0.1978 & \\
\hline \multirow{2}{*}{$\begin{array}{l}\text { Pastoralism } \\
\text { expenditure }\end{array}$} & $\mathrm{T}, \mathrm{E}(3,2)$ & 0.5749 & & T,E $(3,2)$ & 0.5508 & & $\mathrm{~T}, \mathrm{E}(3,2)$ & 0.0672 & $1.035(0.075)$ \\
\hline & & 0.0086 & $1.22(0.08)$ & & 0.0788 & & & 0.0754 & \\
\hline
\end{tabular}

The top statistics for Granger causality for each row of expenditure data tests for causality from patents, the lower number tests for the reverse. 
Table A6: Percentage of Mining patent Applications and Expenditure and of Percentage Gold Exports: Granger Causality and Selected Coefficients

\begin{tabular}{|c|c|c|}
\hline & $\begin{array}{r}\text { Gold E } \\
\text { Two Year Leac }\end{array}$ & $\begin{array}{l}\text { xports Percent } \\
\text { for Granger Causality }\end{array}$ \\
\hline \multirow[t]{2}{*}{ Mining patent applications $\%$} & 0.0866 & \\
\hline & 0.0018 & $0.47(0.06)$ \\
\hline \multirow[t]{2}{*}{ Mining patent expenditure $\%$} & 0.2603 & \\
\hline & 0.0027 & $0.46(0.07)$ \\
\hline
\end{tabular}

